\title{
PENGARUH FAKTOR KOMITMEN PROFESI AKUNTAN, KOMITMEN ORGANISASI KANTOR AKUNTAN PUBLIK DAN KEPUASAN KERJA AUDITOR TERHADAP IMPLEMENTASI AUDIT INDEPENDEN ATAS LAPORAN KEUANGAN
}

\author{
Survei terhadap Akuntan yang bekerja sebagai Auditor pada KAP di Indonesia
}

\author{
Mathius Tandiontong \\ Dosen tetap Fakultas Ekonomi dan Bisnis Universitas Kristen Maranatha di Indonesia
}

\begin{abstract}
Abstrak
Harapan pengguna jasa Kantor Akuntan Publik (KAP) dalam memberikan layanan jasa audit yang berkualitas tinggi, belum terpenuhi secara optimal. Berbagai skandal keuangan masih marak terjadi yang melibatkan praktisi akuntan publik. Hal tersebut berakibat, para pengguna jasa audit meragukan integritas Akuntan Publik. Penelitian ini bertujuan untuk memperoleh bukti empirik guna mengevaluasi besarnya pengaruh komitmen profesi akuntan dan komitmen organisasi KAP terhadap implementasi audit independen atas laporan keuangan. Penelitian ini menggunakan metode survei penjelasan, walaupun uraiannya juga mengandung deskripsi, tetapi sebagai penelitian relasional fokusnya terletak pada penjelasan hubungan antar variabel yang bersifat verifikatif. Variabel yang dioperasionalkan dalam penelitian ini, yaitu: komitmen profesi, komitmen organisasi, kepuasan kerja dan implementasi audit independen yang lebih mendasar kepada indikator-indikatornya. Data dihimpun melalui penyebaran kuesioner ke target responden, serta wawancara terbatas maupun studi dokumentas sebagai upaya menambah unsur penjelas dari hasil survei. Unit analisisnya adalah Kantor Akuntan Publik (KAP) di Indonesia dengan populasi 417 KAP. Penarikan sampel dengan metode proporsional acak sederhana terhadap 79 KAP dengan target respon yang dikirim kuesioner 347 orang akuntan. Tehnik analisis dan pengujian data dilakukan dengan Analisis Structural Equation Modeling (SEM). Hasil penelitian menunjukkan bahwa (1) komitmen profesi akuntan berpengaruh dalam meningkatkan kualitas implementasi audit independen atas laporan keuangan; (2) komitmen Kantor Akuntan Publik berpengaruh dalam meningkatkan kualitas implementasi audit independen atas laporan keuangan; (2) Kepuasan Kerja Auditor berpengaruh dalam meningkatkan kualitas implementasi audit independen atas laporan keuangan; (4) komitmen profesi akuntan, komitmen organisasi KAP, dan Kepuasan Kerja Auditor secara bersama-sama berpengaruh dalam meningkatkan implementasi audit independen atas laporan keuangan. Dengan demikian baik secara parsial maupun secara silmultan, implementasi audit independen atas laporan keuangan dipengaruhi oleh faktor komitmen profesi akuntan, komitmen organisasi KAP, dan Kepuasan Kerja Auditor.
\end{abstract}

Kata Kunci: Komitmen profesi, komitmen organisasi, kepuasan kerja, dan implementasi audit independen atas laporan keuangan.

\footnotetext{
Abstract

Public accounting firms (PAFs) in providing audit services of high quality, yet optimally meet service user expectations. Financial scandals are rife that involve public accounting practitioners. This result, the audit service users doubted the integrity of Certified Public Accountants. This study aims to obtain empirical evidence to evaluate the magnitude of the influence of the accounting profession's commitment and organizational commitment PAFs on job satisfaction auditors and the implementation of an independent audit of financial statements and the implications for audit quality. This study uses a survey method of explanation, although the description also contains a description, but as a relational research focus is on the explanation of the relationship between the variables are verification. Variables are operationalized in this study, namely: professional commitment, organizational commitment, job satisfaction, and implementation independent audit, are more fundamental to the indicators. Data were collected through questionnaires to target respondents, as well as limited interviews and documentation studies in an attempt to add the explanatory elements of the survey results. The unit of analysis is a Public Accounting Firms (PAFS) in Indonesia with a population of 417 PAFs. Proportional sampling with simple random method against a target of 79 PAFs questionnaire response sent 347
} 
people accountant. Techniques of data analysis and testing performed by the Analysis Structural Equation Modeling (SEM). The results showed that the accounting profession's commitment, organizational commitment PAFs, and the Auditor Job Satisfaction influential in the implementation of an independent audit of the financial statements, either simultaneously or partial.

Keywords: implementation of an independent audit of financial statements, and factor of professional commitment, organizational commitment, and job satisfaction.

\section{PENDAHULUAN}

Berbagai skandal akuntansi yang terjadi dalam kurun waktu 10 tahun terakhir ternyata tidak pernah lepas dari peran akuntan. Pengguna Jasa Audit meragukan integritas Akuntan Publik, Setidaknya 10 KAP mendapat sanksi dari pemerintah RI, karena kurang berhasil mengemban misinya melindungi kepentingan akuntan yang dinilai memiliki kontribusi dalam banyak kasus kebangkrutan perusahaan. Pengguna Jasa Audit meragukan integritas Akuntan Publik, sebagai akibat menurunnya kepercayaan publik terhadap implementasi audit independen atas laporan keuangan yang dilakukan oleh akuntan publik, dan belum optimalnya kepuasan pengguna jasa audit.

Arens, Elder dan Beasley (2010) menyatakan profesi akuntan publik memiliki tanggung jawab yang sangat besar dalam mengemban kepercayaan yang diberikan masyarakat, Setidaknya: (1) kewajiban kepada klien, kewajiban kepada hukum biasanya muncul karena adanya kegagalan dalam melaksanakan penugasan audit sesuai dengan waktu yang disepakati, pelaksanaan audit yang tidak memadai, gagal dalam menemukan kesalahan dan pelanggaran kerahasiaan oleh akuntan publik; (2) Kewajiban perdata bagi pihak ketiga (pemegang saham \& calon investor, pemasok, kreditur, karyawan dan pelanggan), kewajiban ini biasanya timbul karena pihak ketiga yang merasa dirugikan atas pengambilan keputusan yang salah, karena mengandalkan laporan keuangan hasil audit yang menyesatkan; (3) Kewajiban pidana bagi pihak ketiga, kewajiban ini biasanya muncul karena akuntan publik ikut terlibat secara langsung bersama-sama dengan klien dalam melakukan tindakan kriminal.

Komitmen profesi sangat diperlukan bagi semua profesi karena jasa profesi dinikmati oleh masyarakat pada umumnya, sehingga masyarakat tidak dirugikan atas jasa yang diberikan oleh profesi tersebut (Boreham, 2000). Profesi akuntan publik harus memiliki integritas, independen dan bebas dari semua kepentingan tersebut, menegakkan kebenaran, kemampuan teknis dan profesionalisme, dan komitmen profesi harus selalu dijaga dengan menempatkan aspek moralitas ditempat yang tertinggi (Gibbins dan Webb, 2001). Akuntan bukan hanya sekedar ahli tetapi harus dapat melaksanakan pekerjaan profesinya dengan menerapkan standar profesi yang disepakati, menjaga akuntabilitas profesi, dan selalu menjunjung tinggi kode etik profesi yang ada (Whan, et al., 2004). Profesi akuntan publik dituntut untuk mengenali kepentingan stakeholder, namun etika profesi tetap terjaga, dalam hal ini tidak terlepas dari komitmen organisasi dimana profesi akuntan publik bekerja, yakni Kantor Akuntan publik (McPhail, 2001).

Skandal akuntansi yang marak terjadi akhirakhir ini, berakibat turunnya kepercayaan masyarakat terhadap profesi akuntan dan kualitas audit yang dihasilkan. Namun demikian belum jelas benar apakah komitmen profesi akuntan publik dan komitmen KAP dapat mempengaruhi kepuasan Auditor (Akuntan publik) maupun implementasi Audit Independen atas Laporan Keuangan, yang diduga akan berimplikasi pada kualitas audit yang dijalankan. 
Banyak pihak yang mendefinisikan kualitas audit, namun tidak ada definisi yang pasti tentang kualitas audit itu sendiri. Hal ini disebabkan tidak adanya pemahaman umum mengenai faktor penyusun kualitas audit dan sering tejadi konflik peran antara berbagai pengguna laporan audit (Sutton, 1993).

Penelitian ini didasarkan pada model yang diperoleh dari fenomena di lapangan yang terbentuk didasarkan pada teori-teori parsial antar model, sehingga dari beberapa teori pendukung tersebut diperoleh suatu bentuk model, seperti penelitian Ahmad, Anantharaman dan Ismail (2012) yang mengkaji komitmen profesi dengan menggunakan dimensi orientasi etik, karakterisik profesi, dan kode etik profesi. Demikian juga penelitian Siregar (2009) yang mengkaji audit independen atas laporan keuangan dengan menggunakan dimensi (1) Perencanaan dan perancangan pendekatan audit, (2) Pengujian atas pengendalian dan pengujian substantif atas transaksi, (3) pelaksanaan prosedur analitis dan pengujian terinci atas saldo, (4) Penyelesaian audit dan penerbitan laporan audit.

Berdasarkan uraian tersebut, maka identifikasi masalah penelitian ini adalah sejauh mana komitmen profesi akuntan, komitmen kantor akuntan publik dan kepuasan kerja auditor berpengaruh terhadap implementasi audit independen atas laporan keuangan.

\section{KERANGKA PEMIKIRAN}

Akuntan publik dalam menjalankan praktik profesionalnya sepenuhnya harus mengikuti aturan etika yang telah ditetapkan dengan berbagai konsekuensinya. Namun demikian, pada umumnya masyarakat tidak mengetahui aturan-aturan yang harus diikuti oleh akuntan publik sehingga terdapat kesenjangan (gap) antara harapan masyarakat dan aturan-aturan yang membatasi praktik akuntan publik. Gap ini terkadang dapat memunculkan persepsi yang salah dari masyarakat terhadap profesi akuntan publik. Salah satu contoh klasik adalah pengguna jasa akuntan publik belum dapat secara tegas memilah pengertian "Audit Failure" dan "Business Failure" (Windsor, 2003, William, 2003 dan Wyman, 2003).

Selain masalah Professional Commitment dan Organizational Commitment, masalah lain yang dihadapi akuntan publik di Indonesia atau diduga mempunyai kontribusi terhadap bisnis akuntan publik di Indonesia adalah kepuasan kerja (Job Satisfaction). Beberapa penelitian terdahulu (Messmer, 2002 dan Camp, 2003) mengemukakan bahwa kinerja dan Kepuasan Kerja mempunyai hubungan, meskipun hubungannya belum konsisten, auditor yang mengalami organizational-professional conflict cenderung mempunyai kinerja yang rendah dan cenderung mempunyai keinginan berpindah (turnover intention) yang tinggi (Harrel, 1986). Penelitian lain (Gregson, 1992) dalam Behavioral Research in Accounting meneliti keterkaitan antara job satisfaction, organizational commitment dan turnover dan peformance hasilnya menunjukkan adanya keterkaitan antara organizational commitment dan turnover. Auditor yang mempunyai organizational commitment tinggi memiliki turnover intention yang rendah, demikian pula sebaliknya. Auditor yang mempunyai organizational commitment dan job satisfaction tinggi juga cenderung mempunyai kinerja yang lebih baik. Peneliti lain yang melakukan penelitian dan hasilnya serupa antara lain: Backman, 2000; dan Aizzat et al, 2001.

Hasil penelitian yang menunjukkan bahwa audit yang dilakukan akuntan tidak dapat secara langsung mempengaruhi kepercayaan pengguna jasa audit. Salah satu penelitian tersebut terkait dengan kontribusi proses audit terhadap keputusan manajemen keuangan perusahaan dapat dijelaskan melalui penelitian Wood (2005). Wood berkesimpulan bahwa auditor memberikan kontribusi bagi manajer keuangan 
berupa pemberian informasi tentang bagaimana melakukan standar akuntansi yang baik dan mengimplementasikan pengawasan. Dengan kata lain pelaksanaan auditing oleh auditor memberikan kontribusi kepada manajer keuangan berupa arahan bagaimana melakukan akuntansi yang benar dan implementasi pengawasan, sedangkan saran-saran yang lain masih belum dapat diimplementasikan karena adanya anggapan bahwa akuntan bukanlah ahli bisnis atau stakeholder. Dengan demikian saran yang diterbitkan oleh auditor eksternal belum tentu dapat dilaksanakan, termasuk oleh manajer keuangan. Hal ini mengindikasikan, proses audit tidak begitu saja mempengaruhi kepercayaan pengguna jasa akuntan.

Penelitian Bruynseels, Knechel dan Willekens (2005) menunjukkan adanya dukungan bahwa auditor spesialis lebih disukai untuk memenuhi kebutuhan going concern perusahaan yang akan bangkrut. Akan tetapi, hasil penelitian ini menunjukkan bahwa para spesialis tidak terikat pada inisiatif operasional. Bahkan terdapat temuan menarik bahwa kantor akuntan yang menggunakan metodologi risiko bisnis cenderung tidak disukai terkait dengan isu going concern. Sejalan dengan hasil penelitian tersebut dapat diketahui bahwa pada perusahaan yang akan bangkrut adanya auditor cenderung tidak akan banyak memberikan banyak perubahan pada perusahaan.

Dengan kata lain rekomendasi dari auditor lebih sesuai untuk berperan sebagai tindakan preventif dan bukan tindakan kuratif. Hal tersebut sejalan dengan bukti empiris lain yang menunjukkan bahwa high quality audits diharapkan oleh pasar untuk melindungi reputasi perusahaan, menurunkan cost of capital, menghindarkan diri dari legal liability dan menghindarkan biaya agensi. Hamilton dan Stoke (2002) menjelaskan peran standar audit sebagai sekumpulan ketentuan best practice. Standarisasi proses audit memungkinkan auditor menjalankan best practice dan memberikan arahan kepada perusahaan yang diaudit.

Dengan demikian, inti manfaat pemeriksaan bukan pada informasi dan rekomendasi saja, melainkan juga pada implementasi rekomendasi audit yang dilakukan oleh entitas yang diperiksa. Dengan kata lain aspek impelementasi rekomendasi audit dinilai sangat penting dalam mendorong entitas pemeriksaan untuk memenuhi rekomendasi yang diharapkan, sebagai salah satu dimensi dari kualitas audit. Namun demikian agent tidak serta merta dapat menjalankan rekomendasi audit, jika pemahaman tentang manfaat audit independen atas laporan keuangan dinilai kurang memadai dan berdampak pada kualitas audit yang diterima. Terkait dengan hal tersebut dalam penelitian ini ingin diketahui secara lebih jelas bagaimana sesungguhnya pengaruh komitmen profesi akuntan dan komitmen kantor akuntan publik terhadap kepuasan kerja auditor dalam implementasi audit independen atas laporan keuangan.

Berdasarkan kerangka pemikiran dapat digambarkan paradigma penelitian ini pada Gambar 1 halaman berikutnya: 


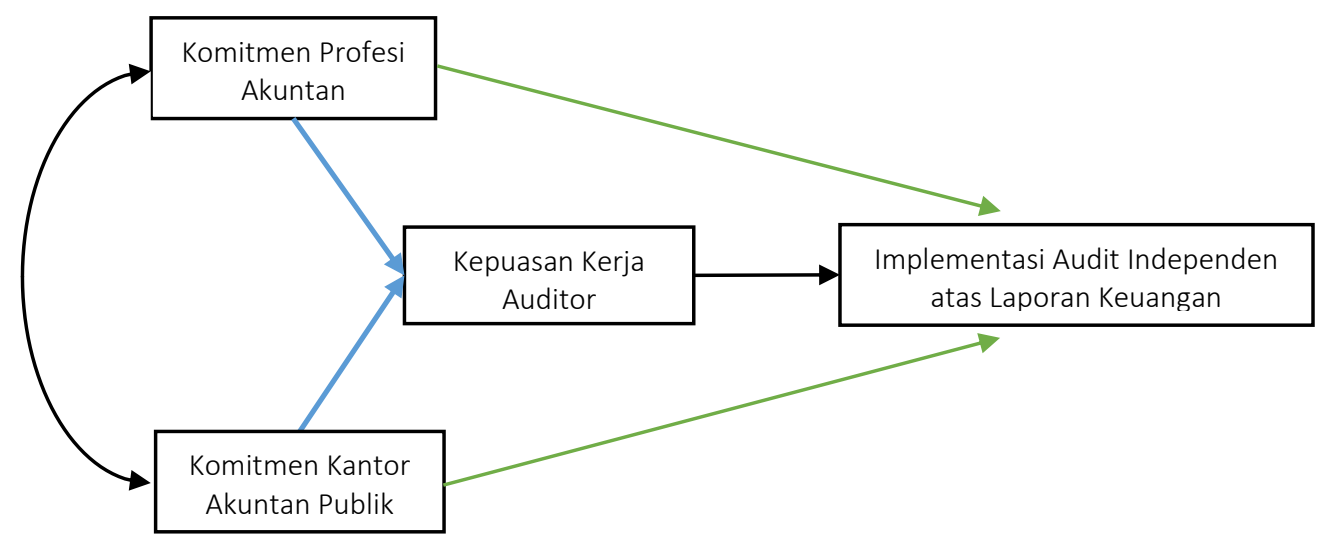

Gambar 1

Paradigma Penelitian

\section{Hipotesis :}

(1) Komitmen profesi akuntan berpengaruh dalam implementasi audit independen atas laporan keuangan;

(2) Komitmen organisasi Kantor Akuntan Publik berpengaruh dalam implementasi audit independen aatas laporan keuangan;

(3) Kepuasan kerja auditor berpengaruh dalam implementasi audit independen atas laporan keuangan;

(4) Komitmen profesi akuntan, komitmen organisasi Kantor Akuntan Publik, dan kepuasan kerja auditor berpengaruh dalam implementasi audit independen aatas laporan keuangan

\section{METODE PENELITIAN}

Penelitian ini menggunakan Metode Survei Penjelasan (Explanatory Survey Method). Bertujuan untuk menguji hipotesis yang telah dirumuskan sebelumnya. Walaupun uraiannya juga mengandung deskripsi, tetapi sebagai penelitian kuantitatif fokusnya terletak pada penjelasan hubungan antar variabel. Konsekuensi penelitian ini diperlukan operasionalisasi variabel yang lebih mendasar kepada indikator-indikatornya. Sesuai dengan hipotesis yang diajukan, penelitian ini digunakan Structural Equation Modeling (SEM), dengan alasan bahwa model ini merupakan pendekatan terintegrasi antara Factor Analysis, Path Analysis, dan Structural Model, dan merupakan analisis data dengan konstruksi konsep.

Variabel penelitian dioperasionalisasikan mengacu pada semua variabel dalam hipotesis yang telah dirumuskan, yaitu: (1) Variabel
Komitmen Profesi Akuntan, yaitu keinginan akuntan (individu) secara sukarela untuk selalu taat pada Standar Profesi, yang meliputi: patuh pada standar auditing, kebijakan pengendalian mutu, standar umum dan standar audit, memahami hak-hak istimewa Akuntan, dan memahami tanggung jawab atas pernyataan keuangan; menjaga Akuntabilitas Profesi, yang meliputi: tanggung jawab pada perencanaan dan pelaksanaan audit, tanggung jawab terhadap profesi, komitmen atas kebenaran dan keadilan, komitmen pada citra Akuntan, komitmen pada perilaku Akuntan, menghindari konspirasi dengan klien, pengungkapan rahasia informasi klien, kewajaran penentuan fee profesi, bebas dari target yg tidak realistis, komunikasi tertulis dengan akuntan terdahulu, dan terhindar dari Related Party (hubungan khusus); mengimplemetasikan Etika Profesi, yang meliputi: tanggung jawab profesi, kepentingan umum, integritas, objektif, independensi, 
kompetensi dan kehati-hatian profesional, kerahasiaan, dan standar teknis; (2) Variabel Komitmen Organisasi Kantor Akuntan Publik (KAP), merupakan keinginan seorang auditor dalam hal ini akuntan secara sukarela untuk selalu terlibat atau loyal terhadap KAP dengan tujuan tertentu. Komitmen organisasi KAP tercermin dari: adanya Komitmen Afektif, yang meliputi: kepedulian dalam karir akuntan, identifikasi dengan pekerjaan akuntan, rasa memiliki akuntan, keterikatan emosional akuntan dengan organisasi KAP, Akuntan bagian dari KAP, makna pribadi pekerjaan akuntan; adanya Komitmen Kontinum, yang meliputi: kebutuhan akuntan dalam KAP, tanggung Jawab KAP, stabilitas kehidupan, pilihan pekerjaan lain, pengorbanan pribadi, tersedia altenatif pekejaan lain selain akuntan; adaya Komitmen Normatif, meliputi: kewajiban pada organisasi KAP, kewajiban moral, perasaan bersalah saat meninggalkan KAP, kesetiaan (loyalitas) organisasi, merasa berhutang budi; (3) Variabel Kepuasan Kerja Auditor, merupakan kondisi yang dialami oleh Akuntan sebagai auditor yang berkerja pada KAP, ketika merasa puas atas jasa yang diberikan dan imbalan yang diterima. Kepuasan yang dialami Akuntan tercermin dari Kepuasan Eksternal dalam Bekerja, meliputi: tingkat kesulitan pekerjaan, kompensasi, kebijakan KAP, lingkungan kerja, promosi, gaya kepemimpinan managing partner, Hubungan antar karyawan, dan Supervisi; Kepuasan Internal dalam Bekerja, meliputi: keinginan untuk berprestasi, pekerjaan auditor itu sendiri, otonomi dalam bekerja, nilai moral, tanggung jawab, keamanan, berbagai layanan sosial; Kepuasan Umum dalam Bekerja, meliputi: kondisi pekerjaan, dan rekan kerja yang menyenangkan;

Unit analisis penelitian adalah Kantor Akuntan Publik, sebagai sumber informasi adalah Akuntan yang berkerja pada Kantor Akuntan Publik di Indonesia. Ukuran populasi penelitian ini adalah 417 Kantor Akuntan Publik. Ukuran sampel penelitian ditentukan oleh bentuk analisis sesuai dengan hipotesis yang diajukan. Berdasarkan hasil perhitungan dengan menggunakan teknik proportional simple random sampling, diperoleh ukuran sampel 79 KAP. Teknik pengumpulan data dilakukan dengan Teknik Komunikasi Tidak langsung menggunakan Kuesioner sebagai instrumen, dan Teknik Komunikasi Langsung dilakukan dengan cara wawancara terbatas. Pengujian kesesuaian model, dilakukan dengan menggunakan beberapa indeks goodness of fit test (GFT), yaitu: nilai probabilitas ( $\mathrm{p}$-value) statistik chi-square, nilai Root Means Square Error of Approximation (RMSEA), Goodness-of-fit Index (GFI), Adjusted Goodness-of-fit Index (AGFI), Normed Fit Index (NFI), Tucker-Lewis Index (TLI) atau Non Normed Fit Indeks (NNFI), dan Comparative Fit Indeks (CFI). Pengujian dan kriteria kesesuaian model diringkaskan seperti terlihat pada Tabel 1.

Tabel 1

Ukuran Goodness of Fit Test

\begin{tabular}{llccc}
\hline \multicolumn{1}{c}{$\begin{array}{c}\text { UKURAN } \\
\text { GOF }\end{array}$} & \multicolumn{1}{c}{$\begin{array}{c}\text { KRITERIA } \\
\text { KESESUAIN MODEL }\end{array}$} & $\begin{array}{c}\text { KRITERIA } \\
\text { PENGUIAN }\end{array}$ & $\begin{array}{c}\text { IMPLIKASI } \\
\text { PADA HO }\end{array}$ & KEPUTUSAN \\
\hline P-value & 1,00 (model fit sempurna) & $\geq 0,05$ & Diterima & Model fit \\
\hline RMSEA & 0,00 (model fit sempurna) & $\geq 0,08$ & Diterima & Model fit \\
\hline $\begin{array}{l}\text { GFI, AGFI, NFLTLI, dan } \\
\text { CFI }\end{array}$ & $\begin{array}{l}0,00 \text { (model tadak fit); } 1,00 \text { (model fit } \\
\text { sempuma) }\end{array}$ & $\geq 0,90$ & Diterima & Model fit \\
\hline
\end{tabular}

Sumber :Hair, et al (2006), danWijanto (2008). 
Pengujian hipotesis dilakukan melalui uji Statistic F dan uji Statistic Student's t. Untuk pengujian simultan dilakukan dengan uji statistic F dengan Kriteria: (1) Jika nilai $F_{\text {hitung }}>F_{\text {tabel }}$ maka $\mathrm{H}_{0}$ Riject, sehingga $\mathrm{H}_{1}$ diterima; (2) Jika nilai $\mathrm{F}_{\text {hitung }}$ $\leq \mathrm{F}_{\text {tabel }}$ maka $\mathrm{H}_{0}$ Not Riject, sehingga $\mathrm{H}_{1}$ ditolak. Sedangkan untuk pengujian parsial, dilakukan dengan menggunakan statistik student's $t$, dengan kriteria: (1) Jika nilai $t_{\text {hitung }}>t_{\text {tabel }}$ maka $\mathrm{H}_{0}$ Riject, sehingga $\mathrm{H}_{1}$ diterima; (2) Jika nilai thitung $\leq t_{\text {tabel }}$ maka $\mathrm{H}_{0}$ Not Riject, sehingga $\mathrm{H}_{1}$ ditolak.

\section{KAJIAN PUSTAKA}

\section{Implementasi Audit Independen atas Laporan Keuangan}

Arens, Elder dan Beasley (2007) menjelaskan bahwa "the most common way for users to obtain reliable information is to have an independent audit performed. Decision makers can then use the audited information on the assumption that it is reasonably complete, accurate, and unbiased. Secara alamiah antara penyedia informasi dan pengguna informasi terdapat perbedaan kepentingan. Berkaitan dengan hal ini Konrath (2002:7-8) secara tegas menguraikan bahwa : "With wide separation between ownership and management, a potential conflict of interest may be assumed to exist between management and stockholders regarding the financial statement. Management, knowing that it is being evaluated by the stockholder on the basis of the financial statements, desires to present the results of its stewardship in the most favorable light. Stockholders, on the other hand, are interested in financial statements that portray as closely as possible the true financial position, results of operations, and cash flows of the company. Given these divergent attitudes toward financial reporting, the role of the independent auditor as impartial and competent attester evolved". Selanjutnya Konrath (2002:9) menjelaskan sebagai berikut: "Up to this point, auditing has been considered only in the form of external, or independent, auditing. The main features of independent audits are that they are conducted by auditors who are independent of management and serve third-party users (e.g., stockholders and creditors). Also, they are limited to the auditee's financial statements and, therefore, are often referred to as financial audits". Dengan demikian yang dimaksud dengan audit independen adalah audit yang dilaksanakan oleh auditor yang independen dari manajemen dan melayani pihak ketiga (seperti pemegang saham dan kreditur). Audit independent atas laporan keuangan sering juga disebut dengan pemeriksaan keuangan.

Standar audit yang telah ditetapkan dan disahkan oleh IAPI pada tahun 2011 terdiri dari sepuluh standar yang dikelompokkan menjadi tiga kelompok besar, yaitu: Standar Umum, Standar Pekerjaan Lapangan, dan Standar Pelaporan. Jika pendapat secara keseluruhan tidak dapat diberikan, maka alasannya harus dinyatakan. Dalam hal nama auditor dikaitkan dengan laporan keuangan, maka laporan auditor harus memuat petunjuk yang jelas mengenai sifat pekerjaan audit yang dilaksanakan, jika ada, dan tingkat tanggungjawab yang dipikul oleh auditor (IAPI-PSAP, 2011).

Standar-standar tersebut di atas dalam banyak hal sering berhubungan dan saling tergantung satu sama lain. Keadaan yang berhubungan erat dengan penentuan dipenuhi atau tidak atau tidaknya suatu standar, dapat berlaku juga untuk standar yang lain. "Materialitas" dan "Risiko Audit" melandasi penerapan semua standar auditing, terutama standar pekejaan lapangan dan standar pelaporan (Venkataraman, Weber dan Willenborg, 2005).

Tujuan dilakukannya audit atas laporan keuangan oleh auditor, adalah untuk memberikan pendapat akuntan atas kelayakan penyajian laporan keuangan, berkenaan dengan posisi keuangan, hasil operasi dan arus uang 
dalam hubungannya dengan prinsip-prinsip akuntansi yang berlaku umum. Oleh karena itu seorang auditor akan memberikan laporan akuntan sebagai perwujudan pendapatnya dari hasil pemeriksaan keuangan yang telah dilakukannya. Dengan perkataan lain, apabila laporan keuangan yang sama diperiksa oleh akuntan atau auditor yang berbeda, maka akan menghasilkan pendapat atau opini yang sama. Apabila tidak demikian, hilanglah arti profesi akuntan karena orang akan mencari auditor atau akuntan pemeriksa yang dapat memberikan suatu opini akuntan yang paling menguntungkan bagi pihak yang akan menunjuknya atau memberikan penugasan sebagai auditor.

Dalam penelitian ini audit independen atas L/K dimaknai sebagai suatu aktivitas audit yang dilakukan kelompok yang sifatnya independen atau tidak memiliki kepentingan terhadap manajemen dan diangkat secara khusus serta memiliki pandangan antara lain bidang akuntansi dan hal-hal lain yang terkait dengan operasional atau kegiatan perusahaan (SPAP IAPI-IAI, 2001; Konrath, 2002; SPKN BPK, 2007; dan Arens, Elder, dan Beasley, 2010). Audit independen atas $L / K$ diukur melalui:

(1) Perencanaan dan Perancangan Pendekatan Audit, terdiri dari 7 indikator, yaitu (a) Perencanaan awal, (b) Informasi mengenai latar belakang, (c) Informasi tentang kewajiban hukum klien, (d) Prosedur analistis pendahuluan, (e) Materialitas dan risiko audit yang dapat diterima dan risiko bawaan, (f) Struktur pengendalian intern dan risiko pengendalian, dan (g) Rencana dan program audit menyeluruh;

(2) Pengujian atas Pengendalian dan Pengujian Substantif atas Transaksi terdiri dari 3 indikator, yaitu: (a) Pengujian atas pengendalian, (b)Pengujian substantif atas transaksi, (c) Kemungkinan salah saji dalam laporan keuangan;

(3) Pelaksanaan Prosedur Analitis dan Pengujian Terinci atas Saldo terdiri dari (a) Rendah, sedang, tinggi, atau tidak diketahui, (b) Prosedur analitis, (c) Pengujian atas pos-pos kunci, (d) Pengujian terinci tambahan;
(4) Penyelesaian Audit dan Penerbitan Laporan Audit terdiri dari 6 indkator, yaitu: (a) Kewajiban bersyarat, (b) Peristiwa kemudian, (c) Pengumpulan bahan bukti akhir, (d) Evaluasi akhir, (e) Penerbitan laporan audit, dan (f) Pembicaraan dengan komite audit dan manajemen

\section{Konsep Komitmen Profesi Auntan}

Ahmad, Anantharaman, dan Ismail (2012) menyatakan komitmen profesional penting bagi profesi akuntansi karena mengarah ke sensitivitas yang lebih besar terhadap isu-isu etika dan keterlibatan meningkat pekerjaan. Komitmen profesional terhadap profesi akuntansi sebaiknya dikembangkan selama pendidikan tersier atau pada tahap sosialisasi antisipatif. Hasil penelitian Sweeney, Quirin, Fisher (2003) terhadap 349 auditor yang mewakili perusahaan-perusahaan internasional, nasional dan regional menunjukkan bahwa ukuran perusahaan berbanding terbalik dengan komitmen profesional, namun komitmen profesi erat kaitannya dengan ketaatan akuntan pada Standar Profesi, Akuntabilitas Profesi yang harus diperhatikan sebagai wujud dari komitmen profesinya, dan etika profesi.

Tidak mudah bagi akuntan publik untuk memenuhi harapan para stakeholder-nya tetapi tetap harus ditingkatkan agar profesi ini mendapat kepercayaan masyarakat. Hal tersebut dinyatakan oleh Kell (2000) sebagai berikut: Ethics is a topic that receiving a great deal of attention throughout our society today. This attention is an indication of both the importance of ethical behavior to maintaining a civil society, and a significant number of notable instances of unetical behavior. The authors believe that ethical behavior is the backbone of the practice of public accounting and diserving of serious study by all accounting student.

Pada penelitian ini menelusuri komitmen profesi akuntan dari dimensi: (1) Ketaatan akuntan pada standar profesi, meliputi: (a) Patuh pada standar auditing, (b) Kebijakan 
Pengendalian Mutu, (c) Standar Umum dan Standar Audit, (d) Memahami hak-hak istimewa Akuntan Publik, dan (e) Memahami Tanggung Jawab atas pernyataan keuangan; (2) Akuntabilitas Profesi, meliputi: (a) Tanggungjawab pada Perencanaan dan Pelaksanaan audit, (b) Tanggung jawab terhadap profesi, (c) Komitmen atas kebenaran dan keadilan, (d) Komitmen pada citra akuntan, (d) Komitmen pada perilaku Akuntan, (e) Menghindari konspirasi dengan klien, (f) Pengungkapan rahasia informasi klien, (g) Kewajaran penentuan fee profesi, (h) Bebas dari target yg tidak realistis, (i) Komunikasi tertulis dengan akuntan terdahulu, dan (j) Terhindar dari Related Party (hubungan khusus); (3) Etika Profesi, meliputi: (a) Tanggung jawab profesi, (b) Kepentingan Umum, (c) Integritas, (d) Objektif, (e) Independensi, (f) Kompetensi dan kehatihatian Profesional, (h) Kerahasiaan, (i) Stnadar Teknis (Konrad, 2002; Chen, Silverthorne, dan Hung, 2006; Bryant, Moshavi, dan Nugen, 2007; Gary, Bennie dan Chen, 2007; Povel dan Winton, 2007; Francis, 2009; Marshall, Smith, Armstrong. 2010; Arens, Elder, dan Beasley, 2010; McDowall, dan Jackling, 2010).

\section{Komitmen Organisasi Kantor Akuntan Publik}

Robbins dan Judge (2009) mendefinisikan organizational commitment sebagai "the degree to which an employee identifies with a particular organization and its goals and wishes to maintain membership in the organization". Organizational Commitment telah didefinisikan dan diukur dengan berbagai cara seperti Yousef (2002), Bryant, Hunton dan Stone (2004), Biggs dan Swailes (2005), dan Cetin (2006), dalam pandangan mereka memiliki kesamaan makna dalam ikatan antara karyawan dengan organisasinya (bond or linking of the employee to the organization), sedangkan berbedaan terletak pada bagaimana ikatan itu terbentuk. Hasil penelitian mengukur "attitudinal commitment".
Attitudinal commitment didefinisikan sebagai berikut: "the relative strength of an individual's identification with and involvement in a particular organization". Hal tersebut tercermin dalam beberapa indikator yaitu: (1) strong belief in and acceptance of the organizaton's goals and values, (2) willingness to exert effort on the organization's behalf, (3) a desire to maintain membership.

Windsor (1995), Weiner dan Vardi (1998), Cuverson (2002), dan Pamell \& Crandall (2003) menganjurkan bahwa organizational commitment terdiri dari tiga komponen yang dapat dibedakan, yaitu: (a) Affective Commitment, (b) Continuance Commitment, dan (c) Normative Commitment. Hasil penelitian para ahli tersebut menunjukkan: (1) Komitmen Afektif (Afffective Commitment) didefinisikan sebagai komitmen yang didasari perasaan secara emosional untuk selalu terlibat dalam organisasi; karyawan dengan affective commitment yang kuat (strong affective commitment) akan terus bekerja pada perusahaan yang bersangkutan karena mereka secara emosional sangat menginginkannya; (2) Continuance Commitment, didefinisikan sebagai keinginan untuk tetap tinggal atau bergabung dengan organisasi karena pertimbangan cost and benefit; (3) Normative Commitment mengemukakan bahwa individu tersebut tetap tinggal di dalam organisasi karena adanya paksaan dari pihak lain (refers to a person's feelings of obligation to stay with an organization because of pressures from others).

Dengan demikian komitmen organisasi (Organizational Commitment) merupakan keinginan seorang auditor dalam hal ini akuntan publik secara sukarela untuk selalu terlibat atau loyal terhadap suatu kantor Akuntan Publik dengan tujuan tertentu. Komitmen Kantor Akuntan dari 3 dimensi, yaitu: (1) Komitmen Afektif, meliputi: (a) Kepedulian dalam karir Akuntan Publik, (b) Identifikasi dengan pekerjaan Akuntan Publik, (c) Rasa Memiliki Akuntan Publik, (d) Keterikatan emosional Akuntan Publik dengan 
Kantor Akuntan Publik, (e) Akuntan Publik bagian dari Kantor Akuntan Publik, (f) Makna pribadi pekerjaan Akuntan Publik; (2) Komitmen Kontinum, meliputi: (a) Kebutuhan Akuntan Publik dalam Kantor Akuntan Publik, (b) Tanggung Jawab Kantor Akuntan Publik, (c) Stabilitas Kehidupan, (d) Pilihan Pekerjaan Lain, (e) Pengorbanan Pribadi, (f) Tersedia altenatif pekejaan lain selain Akuntan Publik; (3) Komitmen Normatif, meliputi: (a) Kewajiban pada Organisasi, (b) Kewajiban Moral, (c) Perasaan Bersalah saat meninggalkan Kantor Akuntan Publik, (d) Kesetiaan (loyalitas) organisasi, (e) Merasa berhutang budi (Feather dan Rauter, 2004; Biggs dan Swailes, 2005; Chen, Silverthorne, dan Hung, 2006; Kreitner dan Kinicki, 2007; Bryant, Moshavi, dan Nugen, 2007; Robbins dan Judge, 2009).

\section{Konsep Kepuasan Kerja (Job Satisfaction)}

Kepuasan Kerja didefinisikan oleh Luthans (2006) sebagai "a pleasurable or positive emotional state resulting from the appraisal of one's job or job experience. Job satisfaction is a result of employee's perception of how well their job provides those things which are viewed as important; Wood et al. (2001): Job satisfaction is the degree to which individuals feel positively or negatively about their jobs"; Kreitner dan Kinicki (2007), menyatakan Kepuasan Kerja adalah respons emosional terhadap pekerjaan seseorang; Robbins dan Judge (2009), menjelaskan bahwa Kepuasan Kerja merupakan sikap umum individu terhadap pekerjaannya.

Aizzat et al (2001); Balfour (1999); Bay dan Greenberg (2001) menyatakan bahwa: (1) Kepuasan Kerja tidak dapat dilihat, tetapi dapat diduga; (2) Kepuasan Kerja sering ditentukan oleh sejauhmana reward memenuhi harapan individu; (3) Kepuasan Kerja mempunyai hubungan dengan faktor-faktor lain yang melekat pada individu; (4) Karyawan pada level yang lebih tinggi cenderung merasa lebih puas karena memiliki otonomi yang lebih besar, pekerjaan yang lebih bervariasi. Dengan demikian kepuasan kerja adalah keadaan emosional yang menyenangkan yang berasal dari penilaian individu atas pekerjaan atau pengalaman kerjanya. Orang yang merasa sangat tidak puas akan pekerjaannya adalah orang yang memiliki banyak harapan namun mendapatkan hasil yang sedikit. Hasil penelitian lain yang berhubungan dengan Kepuasan Kerja (Fogarty, et al, 2000; Bender, Donohue, dan Heywood, 2005; Luthans, 2006; Fogarty, 2011) menunjukkan bahwa faktor yang mempengaruhi kepuasan kerja adalah: (1) Pekerjaan yang menantang; (2) Penghargaan yang sepadan; (3) Kondisi kerja yang mendukung; (4) Rekan kerja yang supportif; (5) Kesesuaian pekerjaan dengan kepribadian individu.

Hasil penelitian Feather dan Rauter (2004), Feinstein dan Vondrasek (2006) menunjukkan bahwa Kepuasan Kerja (KK) mempunyai korelasi (dapat meningkatkan) prestasi. Cara individu menyatakan ketidak puasan di tempat kerja didukung oleh hasil penelitian Testa (2001) sebagai berikut: "employees can express dissatisfaction by: (a) exit, (b) voice, (c). loyalty, (d) neglect. Faktor-faktor tersebut dapat dijelaskan sebagai berikut: (a) Exit: Ketidak puasan yang diungkapkan dengan perilaku yang mengarah untuk meninggalkan organisasi, mencakup pencarian posisi baru, maupun meminta berhenti; (b) Voice: Ketidak puasan yang diungkapkan dengan usaha aktif dan konstruktif untuk memperbaiki kondisi, (c). Loyalty: Merupakan kesetiaan pasif tetapi optimis menunggu membaiknya kondisi, cenderung membela organisasi menghadapi kritik dari pihak eksternal dan percaya organisasi melakukan hal yang tepat, (d) Neglect: Mengabaikan, secara pasif membiarkan kondisi memburuk termasuk absensi, atau datang terlambat, menurunkan kinerja dan meningkatnya kekeliruan yang dilakukan. Gregson (1992) dan Backman (2000), menyatakan bahwa Kepuasan Kerja 
meningkatkan kinerja, produktifitas, menurunkan absensi (ketidak hadiran) dan intention to quit (keinginan berpindah).

Salah satu alat ukur kepuasan kerja yang dikembangkan oleh Smith dan Stone (1992) adalah Job Description Index (JDI) dimana faktorfaktor yang mempengaruhi kepuasan kerja dapat dilihat dari lima hal yaitu : (1) The work itself, (2) Supervision, (3) Coworkers, (4) Pay dan (5) Promotion. Karyawan dalam pekerjaan jasa sering berinteraksi dengan pelanggan, hal itu merupakan sebuah konsekuensi dari organisasi jasa yang harus berfokus pada kepuasan pelanggan. Karyawan yang memiliki kepuasan kerja akan melayani pelanggan drengan baik, sehingga meningkatkan kepuasan dan kesetiaan pelanggan (Pamell dan Crandall, 2003). Hal ini tidak dapat diterapkan pada KAP, karena KAP harus independen dan mementingkan stakeholder laporan keuangan, bukan mementingkan klien.

Dengan demikian Kepuasan Kerja (Job Satisfaction) Auditor merupakan merupakan kondisi yang dialami oleh Akuntan sebagai auditor yang berkerja pada KAP, ketika merasa puas atas jasa yang diberikan dan imbalan yang diterima. Kepuasan yang dialami Akuntan tercermin dari Kepuasan Eksternal dalam Bekerja, meliputi: tingkat kesulitan pekerjaan, kompensasi, kebijakan KAP, lingkungan kerja, promosi, gaya kepemimpinan managing partner, Hubungan antar karyawan, dan Supervisi; Kepuasan Internal dalam Bekerja, meliputi: keinginan untuk berprestasi, pekerjaan auditor itu sendiri, otonomi dalam bekerja, nilai moral, tanggungjawab, keamanan, berbagai layanan sosial; Kepuasan Umum dalam Bekerja, meliputi: kondisi pekerjaan, dan rekan kerja yang menyenangkan (Pamell dan Crandall, 2003; Kreitner dan Kinicki, 2007; Robbins dan Judge, 2009).

\section{HASIL \& PEMBAHASAN}

Deskripsi dari masing-masing variabel berdasarkan tanggapan responden, yaitu 347 Akuntan dari 117 KAP selaku Auditor yang berpraktik pada Kantor Akuntan Publik di Indonesia, dapat diringkaskan ke dalam Tabel 2.

Tabel 2

Rekapitulasi Hasil yang Dicapai Masing-masing Variabel Laten/Variabel Teramati 


\begin{tabular}{|c|c|c|c|c|}
\hline \multirow[t]{5}{*}{1.} & Implementasi Audit Independen atas Laporan Keuangan (AI): & 25.815 & 34.700 & 74.39 \\
\hline & a. Perencanaan dan Perancangan Pendekatan Audit & 8.842 & 12.145 & 72.80 \\
\hline & b. Pengujian atas pengendalian dan pengujian substantif atas transaksi & 3.880 & 5.205 & 74.54 \\
\hline & c. Pelaksanaan prosedur analistis dan pengujian terinci atas saldo & 5.211 & 6.940 & 75.09 \\
\hline & d. Penyelesaian audit dan penerbitan laporan audit & 7.882 & 10.410 & 75.72 \\
\hline \multirow[t]{4}{*}{2.} & Komitmen Profesi Akuntan (KP): & 31.607 & 41.640 & 75.91 \\
\hline & a. Ketaatan pada Standar profesi & 6.531 & 8.675 & 75.29 \\
\hline & b. Akuntabilitas Profesi & 14.509 & 19.085 & 76.02 \\
\hline & c. Etika Profesi & 10.567 & 13.880 & 76.13 \\
\hline \multirow[t]{4}{*}{3.} & Komitmen Organisasi KAP (KO): & 22.013 & 29.495 & 74.63 \\
\hline & a. Komitmen Afektif & 7.653 & 10.410 & 73.52 \\
\hline & b. Komitmen Kontinum & 7.904 & 10.410 & 75.93 \\
\hline & c. Komitmen Normatif & 6.456 & 8.675 & 74.42 \\
\hline \multirow[t]{5}{*}{4.} & Kepuasan Kerja Akuntan Publik (KK): & 22.180 & 27.760 & 79.90 \\
\hline & a. Kepuasan Eksternal dalam Bekerja (Extrinsic Job Satisfaction) & 10.355 & 13.880 & 74.60 \\
\hline & b. Kepuasan Internal dalam Bekerja (Intrinsic Job Satisfaction) & 9.266 & 10.410 & 89.01 \\
\hline & c. Kepuasan Umum dalam Bekerja (General Job Satisfaction) & 2.559 & 3.470 & 73.75 \\
\hline & d. d.Penyelesaian audit dan penerbitan laporan audit & 7.882 & 10.410 & 75.72 \\
\hline
\end{tabular}

Sumber: Hasil Perhitungan WMS, 2012

Pengaruh komitmen profesi akuntan dan komitmen organisasi KAP terhadap kepuasan kerja auditor dalam implementasi audit independen atas laporan keuangan. Secara rinci akan diuraikan berdasarkan hipotesis yang diajukan, secara keseluruhan model yang dihasilkan penelitian ini dapat digambarkan sebagai berikut:

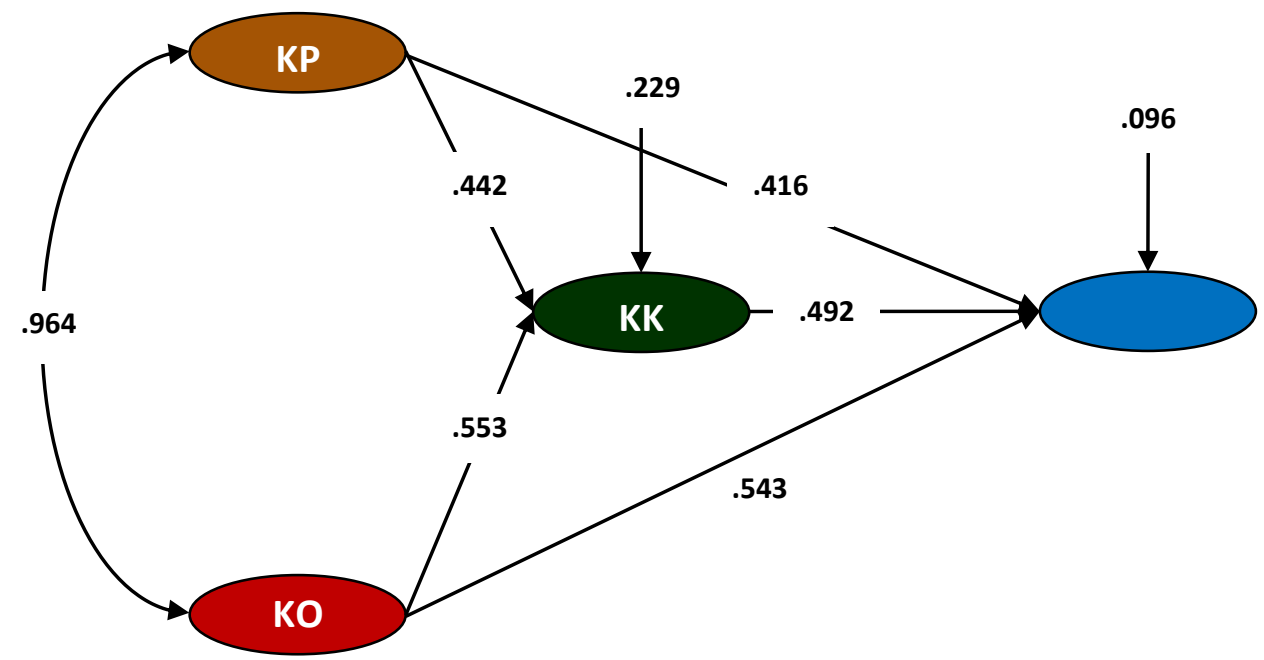

Gambar 2

Model Struktural Implementasi Audit Independen atas L/K (IAI) dan Faktor Komitmen Profesi (KP) dan Komitmen Organisasi (KO), Kepuasan Kerja (KK)

\section{Uji Goodness of fit Statistics}

Hasil ketepatan model yang diperoleh (pengujian model secara simultan atau keseluruhan) ditunjukkan oleh ukuran kesesuaian model (Goodness of fitstatistics) dapat diringkaskan seperti terlihat pada Tabel 3.

Tabel 3

Evaluasi Kriteria Goodness of Fit Indices 


\begin{tabular}{lccl}
\hline Kriteria & Hasil & Nilai Kritis & $\begin{array}{c}\text { Evaluasi } \\
\text { Model }\end{array}$ \\
\hline $\begin{array}{l}\chi^{2} \text { (CMIN) } \\
\text { Df = 3557 }\end{array}$ & 3998,169 & $\begin{array}{c}\text { Diharapkan } \\
\text { kecil }\end{array}$ & Marginal \\
\hline $\begin{array}{l}\text { Significance } \\
\text { Probability }\end{array}$ & 0,0000 & $\geq 0,05$ & Marginal \\
\hline CMIN/DF & 1,124 & $\leq 2,00$ & Baik \\
\hline RMSEA & 0.0640 & $\leq 0,08$ & Baik \\
\hline $\begin{array}{l}\text { Goodness of Fit } \\
\text { Index (GFI) }\end{array}$ & 0,89 & $\geq 0,90$ & Marginal \\
\hline $\begin{array}{l}\text { Normed Fit } \\
\text { Index (NFI) }\end{array}$ & 0,97 & $\geq 0,90$ & Baik \\
\hline
\end{tabular}

Sumber: Data primer diolah, 2012

Hasil pengujian model dengan memperhatikan nilai $\chi^{2}$, maka diperoleh nilai $\chi^{2}$ besar dengan Significance Probability $(0,000)$ lebih kecil dari 0,05. Tetapi karena rasio CMIN dengan DF masih kurang dari 2, maka dapat dinyatakan model struktural yang terbentuk dapat diterima (fit dengan data). Ukuran Goodness of Fit Statistics yang lainnya juga menunjukkan model masih dapat digunakan dimana RMSEA untuk model struktural 0,064 lebih kecil dari nilai kritis 0,8 dan Normed Fit
Index (NFI) model 0,97 lebih besar dari nilai kritis $(0,90)$. Adapun nilai GFI model masuk dalam kriteria marginal. Berdasarkan ukuran kecocokan model yang diperoleh dapat disimpulkan model struktural yang terbentuk sesuai dengan data dan dapat dikatakan memenuhi kriteri Goodness of Fit.

\section{Pengujian Hipotesis:}

Pengujian hipótesis ini menggambarkan pengaruh komitmen profesi akuntan, komitmen oraganisasi Kantor Akuntan Publik, kepuasan kerja auditor dan implementasi audit independen atas laporan keuangan yang dinyatakan dalam hipotesis "Komitmen profesi akuntan, komitmen organisasi Kantor Akuntan Publik, dan kepuasan kerja auditor berpengaruh secara positif dan signifikan terhadap implementasi audit independen atas laporan keuangan baik secara parsial maupun secara simultan"

Tabel 4

Pengaruh KP, KO dan KK terhadap Al

\begin{tabular}{|c|c|c|c|c|}
\hline Koefisien R & $\mathrm{p}$-value & $\begin{array}{r}\mathrm{F} \text { Change \& } \\
\mathrm{t}_{\text {test }} \\
\end{array}$ & $\begin{array}{c}\text { Rsquare } \\
\left(R^{2}\right)\end{array}$ & Ket \\
\hline $\mathrm{KP}, \mathrm{KO}$ dan KK secara simultan terhadap $\mathrm{IAI}=.951$ & .000 & 659.102 & .904 & HoReject \\
\hline KP secara parsial terhadap IAI $=\left(\gamma_{3}=.349\right)^{*}(r=.940)$ & .000 & 9.193 & .328 & HoReject \\
\hline KO secara parsial terhadap IAI $=\left(\gamma_{4}=.459\right) *(r=.944)$ & .000 & 8.566 & .433 & HoReject \\
\hline KK secara parsial terhadap IAI=( $\left.\beta_{1}=.152\right)^{*}(r=.941)$ & .000 & 5.566 & .143 & $\mathrm{H}_{0}$ Reject \\
\hline
\end{tabular}

Komitmen profesi akuntan, komitmen organisasi kantor akuntan publik dan kepuasan kerja auditor berpengaruh positif dan signifikan dalam implementasi audit independen atas laporan keuangan baik secara parsial dan secara simultan, secara fungsi dapat dibuat persamaan sebagai berikut:

$\mathrm{Al}=0,349 \mathrm{KP}+0,459 \mathrm{KO}+0,152 \mathrm{KK}+0,096$
Ket: $A l=$ Audit Independen; $K P=$ Komitmen Profesi; $K O$ = Komitmen Organisasi; KK = Kepuasan Kerja

Berdasarkan hasil penelitian ini menunjukkan bahwa terdapat pengaruh komitmen profesi akuntan, komitmen organisasi KAP dan kepuasan kerja auditor dan implementasi audit independen atas laporan keuangan sudah relevan, karena semua masalah kedua dalam penelitian ini dapat terjawab. 
Berdasarkan penelusuran hipotesis yang diajukan dapat diterima secara signifikan. Dengan demikian jika pendekatan dilakukan secara parsial masih memungkinkan adanya komitmen profesi dan komitmen organisasi yang berpengaruh terhadap kepuasan kerja maupun dalam mengimplemetasikan audit independen atas laporan keuangan. Jika ditelusuri komitmen organisasi Kantor Akuntan Publik umumnya telah diterapkan sebagai kode etik yang dipersyaratkan Institut Akuntan Publik Indonesia dalam standar profesional akuntan publik terkait dengan ketaatan pada standar profesi, akuntabilitas profesi maupun pada etika profesi yang semua ini merupakan dimensi dari komitmen profesi akuntan. Hal tersebut tentu akan sangat berpengaruh terhadap kualitas audit yang pada gilirannya akan berdampak pada aspek lain, seperti kepuasan kerja serta implementasi audit independen atas laporan keuangan. Hasil penelitian ini sejalan dengan hasil penelitian Messier, Emby, Glover, and Prawitt, 2008 yang memperlihatkan bahwa Laporan penting sekali dalam suatu audit atau proses atestasi lainnya karena laporan menginformasikan pemakai informasi mengenai apa yang dilakukan auditor dan kesimpulan yang diperolehnya. Dari sudut pemakai laporan dipandang sebagai produk utama dari proses atestasi, untuk mendapatkan kualitas laporan audit yang baik tentu menuntut perlunya ketaatan pada standar profesi, akuntabilitas profesi, dan etika profesi. Pada dasarnya keberdaan komitmen profesi dan komitmen organisasi memainkan peranan penting dalam implementasi audit independen atas laporan keuangan, namun yang paling penting adalah mampu menciptakan suasana yang menyenangkan bagi auditor dalam bekerja. Hasil penelitian ini sejalan dengan hasil penelitian Aranya dan Ferris (1984) menyatakan penegasan etika profesi merupakan kunci untuk memberikan kepercayaan masyarakat terhadap jasa yang diberikan oleh akuntan publik (auditor independen), apabila etika profesi tidak dipatuhi, maka dampaknya akan muncul berbagai masalah yang merugikan jasa professional yang diberikan.

Pengaruh komitmen profesi akuntan, komitmen organisasi KAP, dan kepuasan kerja auditor menunjukkan pengaruh yang bermakna terhadap implementasi audit independen atas laporan keuangan, namun pengaruh tersebut belum optimum. Hal ini dapat dilihat bahwa masih ada faktor residu, yaitu faktor-faktor selain komitmen profesi, komitmen organisasi dan kepuasan kerja auditor yang juga berpengaruh terhadap implementasi audit independen. Faktor residu tersebut diduga, adalah faktor kesadaran untuk mematuhi peraturan kerja, keinginan untuk membantu auditor lain tanpa pamrih, suasana hati, kualitas interaksi managing partner/partner dengan auditor, masa kerja dan kebersamaan.

Dengan demikian, Komitmen profesi akuntan berpengaruh positif dan bermakna dalam implementasi audit independen atas laporan keuangan, artinya jika komitmen profesi para auditor mengalami peningkatan, maka implementasi audit independen atas L/K juga menagalami peningkatan. Demikian halnya Komitmen organisasi Kantor Akuntan Publik berpengaruh positif dan bermakna dalam implementasi audit independen atas laporan keuangan, artinya jika komitmen organisasi KAP mengalami peningkatan, akan diikuti oleh meningktnya implementasi audit independen atas L/K. Selajuntnya Kepuasan kerja auditor berpengaruh positif dan bermakna dalam implementasi audit independen atas laporan keuangan, artinya jika kepuasan kerja auditor meningkat, akan diikuti oleh peningkatan ilmpementasi audit independen atas L/K. Hal tersebut juga terlihat baik secara simultan maupun secara parsial komitmen profesi akuntan, komitmen organisasi Kantor Akuntan Publik, dan kepuasan kerja auditor berpengaruh positif dan bermakna dalam implementasi audit independen atas laporan keuangan. 


\section{KESIMPULAN}

Berdasarkan hasil penelitian dan pembahasan dapat disimpulkan beberapa hal, yaitu: (1) Komitmen profesi akuntan berpengaruh positif dan bermakna dalam implementasi audit independen atas laporan keuangan; (2) Komitmen organisasi Kantor Akuntan Publik berpengaruh positif dan bermakna dalam implementasi audit independen atas laporan keuangan; (3) Kepuasan kerja auditor berpengaruh positif dan bermakna dalam implementasi audit independen atas laporan keuangan; (4) Komitmen profesi akuntan, komitmen organisasi Kantor Akuntan Publik, dan kepuasan kerja auditor berpengaruh positif dan bermakna dalam implementasi audit independen aatas laporan keuangan. Dengan demikian implementasi audit independen atas laporan keuangan dipengaruhi oleh faktor komitmen profesi akuntan, komitmen organisasi Kantor Akuntan Publik, dan kepuasan kerja auditor. Meskipun demikian masih ada faktor lain yang juga berpengaruh terhadap implementasi audit independen atas laporan keuangan, namun pengaruhnya relatif rendah, yang diduga adalah faktor kesadaran untuk mematuhi peraturan kerja, keinginan untuk membantu auditor lain tanpa pamrih, suasana hati, kualitas interaksi managing partner/partner dengan auditor, masa kerja dan kebersamaan.

\section{REKOMENDASI:}

(1) Hasil penelitian ini menunjukkan komitmen profesi dan komitmen organisasi berpengaruh secara bermakna terhadap kepuasan kerja auditor, namun belum optimum, untuk itu disarankan pada komitmen profesi akuntan masih potensial untuk ditingkatkan yaitu dengan meningkatkan komitmen akuntan atas kebenaran dan keadilan guna memberikan keyakinan atas kesesuaian penugasan audit dengan standar audit yang diterapkan IAPI.

(2) kepada peneliti lain yang berminat untuk melakukan penelitian mengenai implementasi audit independen atas laporan keuangan, dimana aturan bagi auditor untuk mengimplementasikan audit independen belum banyak dimuat, baik dalam peraturan perundangan maupun anggaran dasar Kantor Akuntan Publik.

(3) Peneliti menduga ada faktor lain yang berpengaruh terhadap impelementasi audit independen dan kualitas audit selain komitmen profesi dan komitmen organisasi serta kepuasan kerja auditor. Faktor lain yang dimaksud diduga adalah audit operasional, audit dengan tujuan tertentu, audit investigasi dan kebijakan Kantor Akuntan Publik demi kepentingan pemangku kepentingan (stakeholder). Untuk itu disarankan kepada peneliti lain yang berminat, dapat melakukan penelitian atas pengaruh faktor yang diduga tersebut.

(4) Hasil penelitiaan menunjukkan pada indikator yang membangun audit independen atas laporan keuangan masih ada indikator yang termasuk yang belum optimal, yaitu: (1) pelaksanaan pengujian dan konfirmasi multi pihak atas saldo untuk menentukan status saldo yang ada; (2) Perencanaan awal audit dilakukan secara lengkap dan dikomunikasikan kepada seluruh tim audit; (3) Disusun rencana audit melalui prosedur perencanaan yang lengkap dan menyeluruh sesuai penyusunan program yang berlaku; dan (4) Penerbitan laporan audit dilakukan setelah melalui rapat tim audit dan berbagai kajian yang menyeluruh.

\section{DAFTAR PUSTAKA}

Aranya, N., J. Polick, and J. Amemic. 1981. An Exiamination of Proffesional Commitment in Public Accounting. Accounting, Organizations and Society. Vol. 6. No.4, pp21-280.

Arens, Alvin A., Randal J. Elder and Mark S. Beasley. 2010, Auditing \& Assurance Services An Integrated Approach. 13 ${ }^{\text {th }}$ Edition. New Jersey: Prentice Hall.

Bender, K., Donohue, S. and Heywood, J., 2005. Job satisfaction and gender segregation, Oxford Economic Papers, Vol. 57, No. 3, Oxford, pp. 479-496.

Besacier, Nathalie Gonthier dan Alain Schatt. 2007. Determinants of Audit Fees for French 
Quoted Firms. Managerial Auditing Journal. Vol. 22 No. 2, pp. 139-160

BPKP, 2008. Kode Etik dan Standar Audit. Jakarta: PPPP-BPKP.

, 2008. Peraturan BPK Nomor: 01 Tahun 2007 Tentang Standar Pemeriksaan Keuangan Negara. Jakarta: BPK-RI.

Bradley, S., Petrescu, A. and Simmons, R., 2004. The impacts of human resource management practices and pay inequality on workers' job satisfaction, Working Paper 031, Department of Economics, Lancaster University Management School, available at: http://www.lums.lancs.ac.uk/ publications/viewpdf/000276/

Bryant S. E., Moshavi, D., and T. V. Nugen, 2007. A Field Study on Organizational Commitment, Professional Commitment and Peer Mentonng. Database for Advances in Information System, 38 (2): 61-74

Bulmer, Janelle, et al, 2004. The Diverse Roles of Professional Accountants in Business, Working Paper Seminar, pp. 10-11.

Castle N G, 2007. Assessing Job Satisfaction of Nurse Aides In Nursing Homes: The Nursing Home Nurse Aide Job Satisfaction Questionnaire. Journal of Geontological Nursing, 33 (5): $41-47$

Chang, S., and Lee, M. 2006. Relationship Among Personality Traits, Job Characteristics, Job Satisfaction, and Organizational Commitment: An empirical study in Taiwan. The Business Review. Vol. 6., No. I, pp. 201207

Chen J., Silverthorne, C., and Hung, J. 2006. Organizational Communication, Job Stress, Organizational Commitment, Job Performance of Accounting Professionals in Taiwan and America. Leadership and Organization Development Journal, 27 (4): 242-249
Clugston, M. 2000. The Mediating Effects of Multidimensional Commitment on Job Satisfaction and Intent to Leave. Journal of Organizational Behavior, 21 (4): 477-486

Cohrs, J. C., Abele, A. E., \& Dette, D. E. 2006. Integrating Situational And Dispositional Determinants of Job Satisfaction: Findings from three samples of professional. The Journal of Psychology, 140 (4): 363-395

Daily, Austin dan Robert H. Strawser, 1974. Independent Audits and the reporting practices of banks. Journal of Accountancy

Defond, Mark and Francis, Jere F, 2005, Audit Research After Sarbanes Oxley, Auditing A Journal of Theory and Practice Vol 24 supplement.

Deis, D.R and G.A. Groux. 1992. Determinant of Audit Quality $n$ The Public Sector. The Accounting Review. Juli. P. 463-479.

Dye, R. 1993. Auditing Standards, Legal Liability and Auditor Wealth, Journal of Political Economy, Vol.I01.pg 887-914

Ellwood, Sheila. 1993. Parish and Town Councils: Financial Accountability and Management, Local Government Studies, Vol. 19, p368386.

Fatt, J. P. T., 1995. Ethics and the Accountant, Journal of Business Ethics 14, 997-1004

Feltham, G. A., J. S. Hughes, and D. A. Simunic. 1991. Empirical Assessment of The Impact of Auditor Quality on The Valuation Of New Issues. Journal of Accounting \& Economics 14: 375-399.

Ferguson, Andrew and Bill Rafuse, 2004. Who Audits the auditors? The international Peer Review of the office of the auditors general of Canada-International Journal of Government Auditing, October.

Ferris, KR, 1981, Organizational Commitment and Performance in a professional accounting 
firm. Accounting Organization and Society, Vol 6: 317-326

Fleming, Damon M. dan Robin N. Romanus. 2007. Auditor Industry penalization and Audit Fees Surrounding Section 404 Implementation. Melalui http://papers.ssrR.com/s013/JEUOL'RResult s.cfm?fromname=journal Browse\& journalid=963459. [20/8/2011].

Fogarty, T. J. 2011. The Social Construction of Research Advice: The American Accounting Association plays Miss Lonely hearts. Accounting and the Public Interest (11): 3251

, 2004. Sustained research productivity in accounting: A study of the senior cohort. Global Perspectives on Accounting Education (1): 31-58.

Frankel, R., M. Johnson and K. Nelson: 2002, "The Relation between Auditors" Fees for Nonaudit Services and Earnings Management", The Accounting Review 77(Suppl.), 71-105.

Goodwin, Jenny dan David Goodwin. 1999. "Ethical Judgments Across Cultures: A Comparison between business Students from Malaysia and New Zealand". Journal of Business Ethics 18: 267-281.

Griffin, Paul A., David H. Lont, and Yuan Sun, 2010. Agency Problems and Audit Fees: Further Tests of The Free Cash Flow Hypothesis. Accounting and Finance, Volume 50, Issue 2, pages 321-350.

Gunther, Jeffery W and Rober and More, 2002. Auditing the auditors: Oversight or Overkill ? Federal Reserve Bank of Dallas Economic and Financial Policy Review, Vol 1 No.5

Hall, M., D. Smith, and K. Langfield-Smith. 2005. Accountants' Commitment to Their Profession: Multiple dimensions of processional commitment and opportunities for future research. Behavioral Research in Accounting, 17: 89-109.

Harrel, A.E, Chewning and M Taylor, 1986, Organizational - Professional Conflict and the Job Satisfaction and turnover intentions of Internal Auditor, Auditing: A Journal of Practice and Theory, Spring, pp 109-121

Hay, David dan David Davis. 2002. The Voluntary Choice of An Audit of Any Level of Quality: Auditing: A Journal of Paractice and Theory. Vo. 23 No.2.

Hendriksen, Eldon S., dan Michael Van Breda. 2000. Accounting Theory. $5^{\text {th }}$ Edition, IrwinMcGraw-Hill

Hoitash, Rani, Ariel Markelevich dan Charles A. Barragato. 2007. Auditor Fees and Audit Quality. Managerial Auditing Journal. Vol.22 (8). pp. 761-786

Hunt, Allen K. and Ayalew Lulseged. 2007. "Client importance and non-Big 5 auditors" reporting decisions" Journal of Accounting and Public Policy, Volume 26, Issue 2, March-April 2007, Pages 212-248

Jahangir, N., M. M. Akbar, and N. Begum, 2006. The Impact of Social Power Bases, Procedural Justice, Job Satisfaction, and Organizational Commitment on Employees Turnover Intention. South Asian Journal of Management, 13 (4): 72-88

Jeffrey, C., and N. Weatherholt. 1996. Ethical Development, Professional Commitment, and Rule Observance Attitudes: A study of CPAS and Corporate Accountants. Behavioral Research in Accounting, 8: 8-31.

Jensen, Kevan L dan Jeff L. Payne, 2005. Audit Procurement: Managing Audit Quality and Audit Fee in Respone to Agency Costs. Auditing: A Journal of Practice and Theory Vo. 24 No. 2 Nopember 2005 pp27-48

Kirkman, B. L., and D. L. Shapiro, 2001. The Impact of Cultural Values on Job Satisfaction 
and Organizational Commitment In SelfManaging Work Teams: The Mediating Role of Employee Resistance. Academy on Management Journal, 44 (3): 557-569

Konrath, Laweey F. 2002, Auditing Concepts and applications, A Risk-Analysis Approach, 5th Edition, West Publishing Company.

Lauwers, Timothy J., Robert Ramsay, David H. Sinosan., Jerry R. Strawser, 2007. Auditing and Assurance Service. Second Edition. McGraw-Hill. h-win. New York

Lok, P., and J. Crawford, 2004. The Effect of Organizational Culture and Leadership Style on Job Satisfaction And Organizational Commitment: A Cross-National Comparison. Journal of Management Development, 23 (4): 321-338

Lowensohn, S., L. E. Johnson., R. J. Elder dan S. P. Davies. 2007. "Auditor Specialization, Perceived Audit Quality, and Audit Fee in the Local Government Audit Market." Journal of Accounting and Public Policy, 26,705-732.

Malone, Charles F dan Robin W. Roberts. 1996. Factors Associated with the Incidence of Audit Quality. Auditing: A Journal of Practice and Theory Vo. 15 No. 2.

Marshall, Rex, Malcolm Smith, Robert Armstrong. 2010. Ethical issues facing tax professionals: A comparative survey of tax agents and practitioners in Australia. Asian Review of Accounting. Volume 18 Issue 3, pp. 197 220.

McDowall, Tracey and Beverley Jackling. 2010. Attitudes towards the accounting profession: an Australian perspective Asian Review of Accounting. Volume 18 Issue 3, pp. 30-49.

McPhail, K. J. 2001. The Ethical Challenges of Globalisation: Critical Reflections on the ISBEE 2nd World Congress in Sao Paulo,
Brazil', Business Ethics: A European Review, 10, 78-82.

Meyer JP, et al, 2003, Organizational Commitment and Job Performance: its the nature of the commitment that counts. Journal of Applied Psychology, Vol 74: 152156

Miller, C.L., D. B. Fedor dan R. J. Ramsay. 2006. Effect Discussion of Audit Reviews on Auditors Motivation and Performance. Behavioral Research in Accounting. Vol. 18

Pamell, J. A., and W. Crandall, 2003. Propensity for Participative Decision-Making, Job Satisfaction, Organizational Commitment, Organizational Citizenship Behavior, and Intention to Leave Among Egyptian Managers. Multinational Business Review, Vol. 11 No.l, p. 45.

Paulin, Michèle, Ronald J. Ferguson, and Jasmin Bergeron, 2006. Service Climate and Organizational Commitment: The Importance of Customer Linkages. Journal of Business Research, Vol. 59, pp. 906-915

Pemerintah Republik Indonesia, 2011. UU No 5 tahun 2011 tentang Akuntan Publik.

Robbins, Stephen P., dan Timoty A Judge. 2009. Organizational Behavior. 13 Edition. Person Education, Inc. New Jersey.

Schwepker, Charles H., Jr. 2001. Ethical Climate's Relationship to Job Satisfaction, Organizational Commitment and Turnover Intention in the Salesforce, Journal of Business Research (54), 39-52.

Scott, W. R., 2003. Financial Accounting Theory. $3^{\text {rd }}$ Edition.University of Waterloo-Canada: Prentice Hall

Sutton, S.G. 1993. Toward An Understanding of The Factors Affecting The Quality of The Audit Process. Decision Sciences. Vol. 24. p. 88-105. 
Tubbs, Richard M. 1992. The Effect of Experience on the Auditor's Organization and Amount of Knowledge. The Accounting Review, Vol. 67, No.4, October pp. 783-801.

Wagner John A dan John R. Hollenbeck. 2005. Organization Behaviour: Securing Competitive Advantage. $5^{\text {th }}$ Edition. SouthWestem College Publishing. Thomson Learning.

Wood, Frank and Alan Sangster. 2005. Business Accounting. $10^{\text {th }}$ Edition. New York: Prentice Hall. 